\title{
Uracil-Directed Ligand Tethering: An Efficient Strategy for Uracil DNA Glycosylase (UNG) Inhibitor Development
}

\author{
Yu Lin Jiang, Daniel J. Krosky, Lauren Seiple, and James T. Stivers * \\ Department of Pharmacology and Molecular Sciences Johns Hopkins University School of \\ Medicine, 725 North Wolfe Street Baltimore, MD 21205
}

\begin{abstract}
Uracil DNA glycosylase (UNG) is an important DNA repair enzyme that recognizes and excises uracil bases in DNA using an extrahelical recognition mechanism. It is emerging as a desirable target for small molecule inhibitors given its key role in a wide range of biological processes including the generation of antibody diversity, DNA replication in a number of viruses, and the formation of DNA strand breaks during anticancer drug therapy. To accelerate the discovery of inhibitors of UNG we have developed a uracil-directed ligand tethering strategy. In this efficient approach, a uracilaldehyde ligand is tethered via alkyloxyamine linker chemistry to a diverse array of aldehyde binding elements. Thus, the mechanism of extrahelical recognition of the uracil ligand is exploited to target the UNG active site, and alkyloxyamine linker tethering is used to randomly explore peripheral binding pockets. Since no compound purification is required, this approach rapidly identified the first small molecule inhibitors of human UNG with micromolar to submicromolar binding affinities. In a surprising result, these uracil-based ligands are found not only to bind to the active site, but also to a second noncompetitive site. The weaker noncompetitive site suggests the existence of a transient binding site for uracil during the multistep extrahelical recognition mechanism. This very general inhibitor design strategy can be easily adapted to target other enzymes that recognize nucleobases, including other DNA repair enzymes that recognize other types of extrahelical DNA bases.
\end{abstract}

\section{Introduction}

DNA repair pathways have been traditionally viewed as the cellular quality control machinery that preserves the coding potential of genomes ${ }^{1}$. However, there is emerging recognition that the repair mechanisms evolved to prevent accumulation of the RNA base uracil in DNA play a much broader role in a number of important areas of biomedicine that are divergent from genome preservation. Remarkable examples include the role of the uracil excision repair machinery in the process of generating genetic diversity during antibody maturation in B cells $^{2-4}$, the importance of uracil incorporation and removal in the life cycles of herpes ${ }^{5}$, cytomegalo $^{6}$, pox ${ }^{7,8}$ and type 1 human immunodeficiency viruses (HIV-1) ${ }^{9}$, and the essential role of this pathway in generating pharmacologically active single and double strand DNA breaks during chemotherapy treatment with 5 -flurouracil and methotrexate ${ }^{10,11}$. The key enzyme player in all of these remarkably diverse processes is uracil DNA glycosylase (UNG), which cleaves the glycosidic bond between the uracil base and the deoxyribose sugar in DNA by flipping the uracil nucleotide from the DNA duplex into the enzyme active site (Figure 1A) 12. Given that UNG is emerging as a very interesting pharmacologic target, we have sought out methods for the rapid and efficient identification of small molecule ligands that could inhibit its activity. Although potent nucleic acid-based and proteinaceous inhibitors are

\footnotetext{
* Correspondence should be addressed to J.T.S (jstivers@jhmi.edu).
} 
available that target $\mathrm{UNG}^{13-17}$, there are no small molecule inhibitors for this enzyme, and strategies for the discovery of such ligands are lacking.

One of the most exciting potential applications of small molecule human UNG inhibitors are as antiretroviral agents. Recent findings have established that HIV-1 specifically packages human UNG (hUNG) into virus particles via interaction with the virus encoded integrase protein (Int), or perhaps a ternary complex between UNG, Int and the viral Vpr protein ${ }^{5}, 18$ 25 . hUNG is required for infection of nondividing cells such as macrophages and resting $\mathrm{T}$ cells, and helps maintain a viral reservoir in the host that is crucial for virus spread to the lymphoid organs and T-helper lymphocytes, and ultimately, AIDS pathogenesis 20,26 . UNG is apparently recruited to minimize uracil incorporation into the viral genome in these cells, which have naturally high levels of dUTP, a good substrate for the viral reverse transcriptase $^{27}$. In the absence of UNG, the HIV-1 mutation rate is found to increase by 18fold resulting in extremely inefficient virus replication in nondividing cells 20 , and the virus particles produced from UNG depleted cells are incapable of infecting new target cells ${ }^{9}, 28$. Pharmacologic targeting of a human enzyme required for virus infectivity is extremely attractive because such a target would not be susceptible to the same high mutagenesis rate and resulting drug resistance as viral encoded proteins ${ }^{29}$. Targeting the human enzyme is a viable therapeutic strategy because it is not an essential enzyme. Thus, UNG knock-out mice display no remarkable phenotype, nor do UNG null yeast or human cell lines 30 .

Herein, we report an integrated high-throughput (HTP) platform for discovering small molecule ligands that inhibit UNG. The strategy takes advantage of the extrahelical uracil recognition mechanism of UNG by using the specificity and binding energy of a uracil ligand to target the UNG active site $14,31,32$, and then covalent tethering of random functional groups for exploration of nearby binding pockets (Figure 1B). Library members can be rapidly screened using a robust HTP activity assay, and initial hits are quickly optimized using subsequent structure-activity studies. This tethering approach, which uses efficient oxime chemistry (Figure 2), is related to the "combinatorial target-guided ligand assembly" method of Ellman et $\mathrm{al}^{33}$, but differs in that the uracil ligand specifically targets the active site rather than irrelevant regions of the enzyme. Thus, the hit-rate and binding affinities of early hits are higher than the more random approach of Ellman and colleagues. This synthetic and screening strategy should be easily adaptable for the discovery of inhibitors of other enzymes that recognize extrahelical bases in DNA or free nucleosides.

\section{Results and Discussion}

\section{Synthesis of Uracil-Tethered Oxime Libraries and General Strategy}

We sought an inhibitor development strategy that allowed rapid and economical synthesis of small molecule ligands that explore binding sites near the UNG active site, and which could be used directly in HTP screening applications without purification. One efficient synthesis strategy that meets these criteria is outlined in Figure 2. First, flexible diaminoalkanediol linkers of variable length are synthesized from the corresponding dibromoalkanes (Figure 2A). Then the linkers are used to tether uracil aldehyde binding elements (1-3) to a library of aldehyde binding elements (RCHO) via the formation of stable oxime linkages (Figure 2B). Each tethering reaction is carried out in one well of a 96-well microtiter plate that contains one equivalent uracil aldehyde, one equivalent RCHO library member, and a mixture of diaminoalkanediol linkers $(n=2-6)$. The reactions typically proceed to $85-99 \%$ completion after overnight incubation (DMSO solvent, $37^{\circ} \mathrm{C}$ ), and produce a 1:2:1 statistical mixture of the homodimeric $\left(U^{\wedge} U, R^{\wedge} R\right)$ and heterodimeric $\left(U^{\wedge} R\right)$ oximes for each of the five linker lengths present (see Methods and Supplemental Figure S1). Although two geometric configurations are possible, oxime derivatives with bulky substituents are generally found to be $\geq 95 \%$ in the trans configuration ${ }^{34}$. The unpurified oxime mixtures were directly screened 
for inhibition of $\mathrm{UNG}$ at $\sim 100 \mu \mathrm{M}$ total oxime concentration to ensure that each component in the mixture is present at a concentration in the range 5 to $10 \mu \mathrm{M}$. If significant inhibition is observed by any mixture, the linker length and RCHO binding element that gave rise to the inhibition can be identified by resynthesis of the individual oximes using a single linker length in each reaction (see below).

An important aspect of this approach is that the uracil homodimers present in some reaction mixtures are inhibitory even in the absence of any active heterodimer. For instance, the purified homodimers of various lengths that are based on 6-formyluracil (3) give rise to about $22 \%$ inhibition in all the mixtures based on $\mathbf{3}$ under the screening conditions (not shown). In contrast, the homodimers of $\mathbf{1}$ and $\mathbf{2}$ show no detectable inhibition under the same conditions. Thus, the screening assay must be robust enough to detect any additional inhibition resulting from an active heterodimer in the mixture. Spectroscopic results for determining the purity and composition of representative reaction mixtures are available (see Supporting Information).

\section{High-Throughput Screening of Uracil-Oxime Libraries}

To test this directed library approach, we tethered the three uracil aldehydes $(\mathbf{1}, \mathbf{2}, \mathbf{3})$ shown in Figure 2 to 14 aldehyde binding elements (RCHO) using the variable length diaminoalkanediol linkers (see Supporting Information Table S1 for RCHO structures). This library of uracillinked binding elements was screened for inhibition of hUNG using a high-throughput molecular beacon activity assay (Figure 3) ${ }^{35}$. In this assay, one DNA strand is labeled with a fluorescent 5'-FAM, and the complementary strand is modified with a $3^{\prime}$-dabsyl moiety that serves to efficiently quench the fluorescence of the FAM group through contact quenching. To increase stability, the two DNA strands are linked in a hairpin configuration using an 18 atom polyethylene glycol linker. When the substrate DNA is exposed to UDG, multiple uracils are removed, and eventually the two paired strands of the hairpin spontaneously separate, thus removing the dabsyl quencher from the proximity of the FAM group, and resulting in a 6-fold increase in the fluorescence of the system (Figure 3A). Under the assay conditions, the hairpin DNA substrate has a $K_{\mathrm{m}}=164 \pm 10 \mathrm{nM}$ and $k_{\mathrm{cat}}=0.33 \pm 0.01 \mathrm{~s}^{-1}$ (Figure 3B). To enhance detection of competitive inhibitors during HTP screening we employed a molecular beacon substrate concentration equivalent to $1 / 3 K_{\mathrm{m}}(50 \mathrm{nM})$. Representative HTP screening results for several inactive and active oxime mixtures are shown in Figure 4 ([Total oxime] $=100$ $\mu \mathrm{M})$.

Several activity trends emerged immediately from the screening results shown in Figure 4. First, none of the mixtures derived from the uracil N1-acetaldehyde binding element (1) were inhibitory at the concentration used in the screen. In addition, none of the $\mathrm{U}^{\wedge} \mathrm{U}$ homodimers derived from $\mathbf{2}$ were found to be inhibitory, nor were any of the $\mathrm{R}^{\wedge} \mathrm{R}$ homodimers regardless of the linker length. (Inhibition by the homodimers is automatically assessed because these are present in multiple reaction mixtures.) In contrast, one oxime mixture derived from uracil aldehydes $\mathbf{2}$ and $\mathbf{3}$ and $\mathrm{RCHO}=2,4$ dihydroxybenzaldehyde (13) showed inhibitory activity in the range 15 to $100 \%$, indicating that active heterodimers were present. The structures of the active heterodimers present in these two oxime mixtures are shown at the top of Table 1.

The two active mixtures were deconvoluted with respect to linker length by individually synthesizing each oxime dimer using a single diaminoalkanediol linker per reaction (Chart 1). At this stage we did not separate the homodimers from the active heterodimers in the mixtures. For the oxime dimers derived from 5-formyluracil (2) and 2, 4-dihydroxybenzaldehyde (13), a broad dependence on linker length was observed with length $n=2$ being most favorable for inhibitory activity (i.e. mixed oxime $\mathbf{2}-(2)-\mathbf{1 3}$, Chart 1 ). In contrast, a very stringent linker length of $n=3$ was required for maximal inhibitory activity with the oxime mixture derived from 6-formyluracil (3) and 2, 4-dihydroxybenzaldehyde (13) to form mixed oxime 3-(3)-13 (Chart 1). To confirm these results, 2-(2)-13 and 3-(3)-13 were separated from their respective 
homodimers using reversed phase HPLC (see Methods), and the concentration dependence of

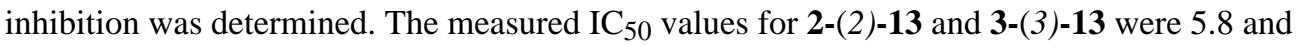
$1.1 \mu \mathrm{M}$, respectively (Fig. 5).

\section{Structure Activity Relationships}

In an effort to find more potent inhibitors based on the 3-(3)-13 scaffold, twenty-five commercially available benzaldehyde precursors were purchased (18-42, cf. Supporting Information Table S2). The HTP screen was then performed on this set of oxime mixtures (3(3)-R) in an identical fashion as described above. This structure-activity study established that the 3- and 4-hydroxyl groups of 3-(3)-13 were essential for activity because alkylation or halogen substitution at these positions had a substantial deleterious effect on inhibitory activity (see Supporting Information Table S2). Thus, hydrogen bond donating groups at the 3- and 4positions of the benzyl ring appear to be essential.

One compound in this series with an additional hydroxyl group at the 2-position of the benzyl ring (3-(3)-27), showed a 3-fold greater potency than 3-(3)-13 (Figure 5, $\mathbf{\square})\left(\mathrm{IC}_{50}=0.3 \mu \mathrm{M}\right.$ ). To further investigate SARs based around the 3-(3)-27 scaffold, we synthesized four more 3, 4-dihydroxybenzaldehyde analogues (43-46, Table 2), where the substituent at the 2-position was varied $\left(\mathrm{R}=\mathrm{F}, \mathrm{Cl}, \mathrm{Br}\right.$ or $\left.\mathrm{NO}_{2}\right)$. Within this series there was a strong trend correlating with atomic size for the halogens, with the smaller fluorine substituent binding 16-fold more tightly than bromine. However, no substituent in this series was more effective than the 2-hydroxyl group. In conclusion, the binding pocket for the 2 -substituent favors a hydrogen bond donating group with a van der Waals radius smaller than chlorine.<smiles>O=c1cc(/C=N/OCCCO/N=C/c2cc(O)c(O)cc2O)[nH]c(=O)[nH]1</smiles>

\section{$3-(3)-27$}

\section{Inhibition Mechanisms of 3-(3)-27, 2-(2)-13 and Uracil}

Although the uracil-directed ligand tethering strategy is expected to produce competitive inhibitors of UNG, we thoroughly investigated whether this assumption was true. The detailed mode of inhibition by 3-(3)-27 and 2-(2)-13 was evaluated by varying both substrate and inhibitor concentrations (Fig. 6A and 6B). Standard double reciprocal plots of $1 / k_{\text {obsd }}$ against 1/[DNA] at increasing concentrations of 3-(3)-27 showed no significant intercept effects establishing a competitive aspect to the inhibition (Figure 6A). However, a secondary plot of the Lineweaver-Burk slopes against [3-(3)-27] showed a parabolic response consistent with the presence of at least two inhibitor binding sites (Figure 6A, inset) ${ }^{36}$. Global discrimination fitting of the inhibition data by computer simulation with the program Dynafit using competitive, noncompetitive, uncompetitive, mixed-type, two-site competitivenoncompetitive, and two-site competitive-uncompetitive inhibition mechanisms unambiguously confirmed the presence of two inhibitory binding sites for 3-(3)-27 (see Supplemental Information) ${ }^{37}$. Simulations clearly indictated that the first tight site is competitive with respect to substrate. Although the simulations indicated a slight statistical advantage for a partial mixed-type inhibition mode for the second weaker site, it was difficult to eliminate an uncompetitive mode for this site. Using the criterion of Occam's razor, the inhibition parameters for 3-(3)-27 are reported in Table 3 using the simulation results for the competitive-partial uncompetitive mechanism (Scheme 1). 
Like its 6-substituted analog, initial inspection of the Lineweaver-Burk analysis of 2-(2)-13 indicates mixed-type inhibition with a strong preference for binding to the free enzyme (i.e. slope effects, Figure 6B). However, in contrast to 3-(3)-27, the secondary plot of the Lineweaver-Burk slopes versus 2-(2)-13 concentration is hyperbolic, indicating that binding of 2-(2)-13 results in partial inhibition (Figure 6B, inset) ${ }^{36}$. Because binding to the active site would result in complete inhibition, 2-(2)-13 most likely binds to the noncompetitive site observed for 3-(3)-27. Global discrimination fitting of the inhibition data by computer simulation confirmed this inhibition mechanism (Scheme 1), and provided the inhibition constants reported in Table 3. These observations strongly indicate that 2-(2)-13 binds to a site distinct from the active site, although DNA binding is strongly antagonistic to inhibitor binding (Table 3). In summary, the inhibition mechanisms of 3-(3)-27 and 2-(2)-13 indicate that two inhibition modes exist for these uracil derivatives: one mode competitively targets the active site, the second weaker mode is noncompetitive or uncompetitive with respect to substrate binding. These data, quite surprisingly, suggested the presence of two uracil binding sites on human UNG.

To further investigate the interesting possibility of two uracil binding sites on UNG we performed a mode of inhibition analysis for uracil itself (Fig. 6C). Confirming this initial expectation, inhibition by uracil involves two sites. The first site is competitive and the second is partially uncompetitive. Accordingly, the Lineweaver-Burk slope replot was slightly parabolic indicating that inhibition involved binding of more than one molecule of uracil, and the intercept replot was hyperbolic indicating a partial uncompetitive mode. These characteristics of the inhibition by uracil combine the features observed for 3-(3)-27 and 2(2)-13, and establish that the two site binding of 3-(3)-27 is not attributable to the trihydroxybenzaldoxime moiety, but instead, arises from the uracil functionality itself.

\section{Implications for Two Uracil Binding Sites}

Why would UNG have a second uracil binding site? Although the answer to this question cannot be firmly established by inhibition data alone, an intriguing role for this site during the mechanism of uracil base flipping is supported by several different experimental findings. First, kinetic experiments following the pathway of uracil flipping from duplex DNA have detected a weakly bound intermediate state of uracil that precedes its attainment of the final extrahelical state seen in the crystal structure (Figure 1A) $)^{15}, 38-40$. Solution and solid state NMR studies of uracil flipping support the existence of a weak uracil binding site because UNG is found to transiently stabilize thymine and other uracil congeners in an extrahelical conformation, without these bases gaining full access to the uracil active site pocket ${ }^{41,42}$. Relevant to these observations, the crystal structure of herpesvirus UDG bound to pTTTp shows that the $5^{\prime} \mathrm{T}$ is bound in the mouth of the active site pocket in a manner that is consistent with a transient state on the pathway for base flipping of uracil ${ }^{43}$. Finally, the crystal structure of another base flipping DNA repair enzyme, human 8-oxoguanine DNA glycosylase, suggests that this related enzyme can flip the normal base guanine into a discrimination pocket that was distinct from the active site pocket that only accommodates 8-oxoguanine ${ }^{44}$. These combined data provide a compelling case for a generalized pathway for base flipping involving transient enzyme stabilization of at least one extrahelical intermediate state before the base is docked into the active site. Based on the observation that 2-(2)-13 is excluded from the active site but that 3(3)-27 and uracil can occupy both sites, we surmise that the relative binding affinities for each site might depend on the bulkiness of the substituent at the 5-position of uracil. In other words, uracil congeners with small substituents at the five position (such as hydrogen in the case of 3-(3)-27) would favor binding to the active site, and uracil derivatives with bulkier substituents (such as the dihydroxybenzaldoxime of 2-(2)-13) would be sterically excluded from the active site, but could gain access to the weaker less selective site. Indeed, it is well known that the active site of UNG uses the bulky side chain of a tyrosine to exclude thymidine (5-methyluracil) 
$14,45-47$, yet 6-substituted uracil derivatives such as 3-(3)-27 have been generally observed to bind to the active site ${ }^{14}$. Thus, the uracil-based inhibitors found here have revealed a possible pyrimidine discrimination site that may be employed during the multistep extrahelical uracil recognition mechanism. It should be noted that the noncompetitive inhibition mode for 2-(2)-13 requires that the final extrahelical state can be attained, albeit inefficiently, even when the transient uracil binding site is occupied by the inhibitor. In contrast, the partial uncompetitive mechanism for binding of 3-(3)-27 to its second site does not present the same apparent discrepancy, because for uncompetitive inhibition, the compound binds after the substrate is fully inside the active site pocket (see above).

\section{Inhibition by the Untethered Parts}

It is of interest to ask how well uracil-directed ligand tethering has performed. To dissect the energetic contributions of the formyluracil and hydroxybenzaldoxime binding elements of 3(3)-27 and 2-(2)-13, we synthesized the methyl oxime derivatives of aldehydes $\mathbf{2}, \mathbf{3}, \mathbf{2 7}$ and $\mathbf{1 3}$ as shown in Scheme 2. These methyl oxime derivatives are reasonable mimics of the two individual binding elements and in principle could provide an energetic analysis of the binding affinities of the two separate elements. If the sum of the binding energies of each element equals the entire binding free energy of the whole tethered molecule, then it may be concluded that (i) the tether is energetically inert with respect to binding, and (ii) the binding of one element does not affect the other by induced strain or forcing a tighter fit. If the whole tethered molecule binds much more weakly or tightly than expected from the summation of the binding free energies of the two individual binding elements, then nonadditive energetic effects are present. Such effects would indicate either an energetic penalty for tethering (antagonistic binding of the parts), or alternatively, a nonadditive energetic benefit (synergistic binding of the parts) 48,49 .

Comparison of the binding affinity of 3-(3)-27 to its competitive site $\left(K_{\mathrm{c}}{ }^{3-(3)-27}=0.32 \mu \mathrm{M}\right)$ with that of the 6-formyluracil $O$-methyl oxime binding element alone (51) allows estimation of the free energy benefit of tethering the trihydroxybenzaldoxime binding element to the 6formyluracil oxime part. Conversely, comparison of the binding affinity of 3-(3)-27 with that of the trihydroxybenzaldoxime $O$-methyl ether (48) allows estimation of the free energy benefit of tethering the 6-formyluracil oxime binding element to the trihydroxybenzaldoxime part. The 6-formyluracil $O$-methyl oxime $\mathbf{5 1}$ shows a cleanly competitive mode of inhibition with $K_{\mathrm{c}}{ }^{\mathbf{5 1}}=45 \pm 2 \mu \mathrm{M}$ (Table 4, data not shown). Thus, the enhancement in the free energy of binding upon addition of the trihydroxybenzaldoxime (THB) part to the 6-formyluracil oxime element is $\Delta \Delta G^{\mathrm{THB}}=-R T \ln \left(K_{\mathrm{i}}^{\mathbf{3}-(3)-\mathbf{2 7}} / K_{\mathrm{i}}^{\mathbf{5 1}}\right)=-3 \mathrm{kcal} / \mathrm{mol}$. We were unable to perform a similar energetic analysis with the trihydroxybenzaldoxime $O$-methyl ether $(\mathbf{4 8})$ due to its extremely weak binding ( $9 \%$ inhibition at $1 \mathrm{mM}$ concentration, data not shown). Similarly, an energetic analysis of the binding elements comprising 2-(2)-13 was not possible because of the extremely weak inhibition by the 5 -formyluracil $O$-methyl oxime (50) and the dihydroxybenzaldoxime $O$-methyl ether (47). Nevertheless, the 140 -fold greater binding affinity of 3-(3)-27 as compared to the 6-formyluracil $O$-methyl oxime binding element (51) alone indicates that a large benefit can be derived from tethering 50 .

\section{Experimental Section}

\section{Reagents and General Methods}

All chemicals were purchased from commercial sources without further purification unless otherwise stated. The ${ }^{1} \mathrm{H},{ }^{13} \mathrm{C}$ and ${ }^{19} \mathrm{~F}$ NMR spectra were recorded on a $400 \mathrm{MHz}$ Varian Innova instrument. The spectra were recorded in deuteriochloroform $\left(\mathrm{CDCl}_{3}\right)$ or in hexadeuteriodimethylsulfoxide (DMSO- $\mathrm{d}^{6}$ ). The chemical shifts of protons are given in ppm with TMS as internal standard. The chemical shifts of carbons are obtained in ppm with solvents 
as internal standards. That of fluorine is given in ppm with $1 \%$ trifluoroacetic acid in DMSO$\mathrm{d}^{6}$ as an external standard. Most of oximes were purified by HPLC using aqueous triethylammonium acetate (TEAA) as a running buffer. Therefore, TEAA was not completely removed and it appeared in the NMR spectra. Accordingly, proton and carbon chemical shifts of TEAA were not listed during the characterizations of the oximes. During the purification of the oxime 3-(3)-27, 2-mercaptoethanol was used as an anti-oxidant. Therefore, small amounts of this compound and its oxidation product are also present in the oxime 3-(3)-27. Flash chromatographies were performed with silica (70-230 mesh from Sorbent Technologies) and monitored by thin layer chromatography (TLC) with silica plates (Merck, Kieselgel 60 F254).

\section{Synthesis of Alkyl Hydroxyamines}

$O, O^{\prime}$-Diaminoalkanediol linkers of variable length (ethyl, propyl, butyl, pentyl, hexyl) were prepared from the corresponding dibromoalkanes in two steps according to literature procedures (Figure $2 \mathrm{~A}$ ) $33,51,52$.

\section{General Synthesis of Tethered Oxime Dimers}

A set of 14 aryl aldehydes (4-17, cf. Supplementary Information, Table S1) was selected for library synthesis for coupling to the three uracil containing aldehydes $(\mathbf{1}, \mathbf{2}, \mathbf{3}$, Figure 2$)$ using the $O, O^{\prime}$-diaminoalkanediol linkers as follows. To each 0.5 -ml well of a Matrix microtiter plate was added a DMSO stock solution of AcOH $(20 \mu \mathrm{l}, 150 \mathrm{mM}, 3 \mu \mathrm{mol})$, uracil aldehyde 1,2 or $3(20 \mu \mathrm{l}, 150 \mathrm{mM}, 3 \mu \mathrm{mol})$ and a single aryl aldehyde $(20 \mu \mathrm{l}, 150 \mathrm{mM}, 3 \mu \mathrm{mol})$. The plate was carefully agitated to make the solutions homogenous. To each of the uracil-aryl aldehyde mixture was added a DMSO solution of the $O, O^{\prime}$-diaminoalkanediol linkers containing each of the five linker lengths in equal proportion $(22 \mu \mathrm{l}, 150 \mathrm{mM}, 3.3 \mu \mathrm{mol}$ total amine equivalents). The plate was sealed, further agitated and incubated in an oven for $12 \mathrm{~h}$ at $37^{\circ} \mathrm{C}$.

The most potent inhibitors from this first screen 2-(2)-13 and 3-(3)-13) were synthesized in larger scale and thoroughly characterized after HPLC purification of the heterodimers:

2-(2)-13: ${ }^{1} \mathrm{H}$ NMR (400 MHz, DMSO-d 6 ): $\delta 8.05(\mathrm{~s}, 1 \mathrm{H}), 7.91(\mathrm{~s}, 1 \mathrm{H}), 7.78(\mathrm{~s}, 1 \mathrm{H}), 7.04(\mathrm{~s}$, $J=2.4 \mathrm{~Hz}, 1 \mathrm{H}), 6.86(\mathrm{~m}, 1 \mathrm{H}), 6.74(\mathrm{~d}, J=8.0 \mathrm{~Hz}, 1 \mathrm{H}), 4.26(\mathrm{~s}, 1 \mathrm{H}) ;{ }^{13} \mathrm{C} \mathrm{NMR}(100 \mathrm{MHz}$, DMSO-d $\left.{ }_{6}\right): \delta 162.40,151.04,149.25,147.92,145.75,142.74,140.66,123.05,119.88,115.74$, 113.10, 104.31, 71.82, 71.54. UV/Vis: $\lambda_{\max } 275 \mathrm{~nm}$; HRMS (m/z): $[\mathrm{M}+\mathrm{Na}]^{+}$calcd for $\mathrm{C}_{14} \mathrm{H}_{14} \mathrm{~N}_{4} \mathrm{O}_{6} \mathrm{Na}$, 357.08; found, 357.08 .

3-(3)-13: ${ }^{1} \mathrm{H}$ NMR (400 MHz, DMSO-d 6 ): $\delta 9.10$ (bs, H), 8.01 (s, $\left.1 \mathrm{H}\right), 7.94(\mathrm{~s}, 1 \mathrm{H}), 7.04$ (d, $J=1.6 \mathrm{~Hz}, 1 \mathrm{H}), 6.82(\mathrm{~d}, J=7.6 \mathrm{~Hz}, 1 \mathrm{H}), 6.74(\mathrm{~d}, J=7.6 \mathrm{~Hz}, 1 \mathrm{H}), 5.78(\mathrm{~s}, 1 \mathrm{H}), 4.26(\mathrm{t}, J=$ $6.8 \mathrm{~Hz}, 2 \mathrm{H}), 4.12(\mathrm{t}, J=6.0 \mathrm{~Hz}, 2 \mathrm{H}), 2.06(\mathrm{t}, J=6.8 \mathrm{~Hz}, 2 \mathrm{H}) ;{ }^{13} \mathrm{C}$ NMR $(125 \mathrm{MHz}$, DMSO$\left.\mathrm{d}_{6}\right): \delta 163.95,151.15,148.96,148.04,145.89,144.73,142.23,123.12,119.83,115.81,113.15$, 101.60, 71.94, 69.76, 28.46; UV/Vis: $\lambda_{\max } 273 \mathrm{~nm}$; HRMS (m/z): $[\mathrm{M}+\mathrm{H}]^{+}$calcd for $\mathrm{C}_{15} \mathrm{H}_{17} \mathrm{~N}_{4} \mathrm{O}_{6}$, 349.11; found, 349.11 .

The second set of oxime dimers based on the 3-(3)-13 hit discovered in the first screening round were synthesized in an identical fashion as described above using uracil aldehyde $\mathbf{3}$ and hydroxybenzaldehydes 18 through $\mathbf{4 2}$, and the $O, O^{\prime}$-diaminopropanediol linker (cf.

Supplementary Information, Table S2). The most potent inhibitor identified from this second round of screening (3-(3)-27) was synthesized in larger scale and thoroughly characterized. 3(3)-27: ${ }^{1} \mathrm{H}$ NMR (400 MHz, DMSO-d 6 ): $\delta 9.10(\mathrm{bs}, \mathrm{H}), 8.21(\mathrm{~s}, 1 \mathrm{H}), 7.94(\mathrm{~s}, 1 \mathrm{H}), 6.88(\mathrm{~s}, 1$ H), $6.31(\mathrm{~s}, 1 \mathrm{H}), 5.78(\mathrm{~s}, 1 \mathrm{H}), 4.28(\mathrm{t}, J=6.0 \mathrm{~Hz}, 2 \mathrm{H}), 4.10(\mathrm{t}, J=6.0 \mathrm{~Hz}, 2 \mathrm{H}), 2.06(\mathrm{~m}, 2$ $\mathrm{H}) ;{ }^{13} \mathrm{C}$ NMR (125 MHz, DMSO-d 6 ): $\delta 163.91,151.04,150.25,149.17,146.90,144.63$, $142.20,138.73,112.76,107.78,103.56,101.69,71.90,69.77,28.38$; UV/Vis: $\lambda_{\max } 286 \mathrm{~nm}$; 
ESI (m/z): [M+H] $]^{+}$calcd for $\mathrm{C}_{15} \mathrm{H}_{18} \mathrm{~N}_{4} \mathrm{O}_{7}, 366$; found, 366. [M+Na $]^{+}$calcd for

$\mathrm{C}_{15} \mathrm{H}_{17} \mathrm{~N}_{4} \mathrm{O}_{7} \mathrm{Na}, 388$; found, 388. [M-H] $]^{-}$calcd for $\mathrm{C}_{15} \mathrm{H}_{16} \mathrm{~N}_{4} \mathrm{O}_{7}, 364$; found, 364.

\section{Isolation and Purification of Oxime Dimers using HPLC}

All of the most active oxime heterodimers were purified by HPLC using a Phenomenex Aqua reversed phase C-18 HPLC column $(250 \mathrm{~mm}, 10 \mathrm{~mm}, 5 \mu \mathrm{m})$. Most of the oximes were purified using gradient elution from 0 to $30 \% \mathrm{CH}_{3} \mathrm{CN}$ in $0.1 \mathrm{M}$ aqueous TEAA over the course of $2 \mathrm{~h}$ using UV detection at $254 \mathrm{~nm}$. An exception was oxime 3-(3)-27, which is prone to air oxidation. In this case, $25 \mathrm{mM}$ 2-mercaptoethanol was added to both of the running buffers. The oximes all eluted with baseline resolution in the order: U-U homodimer, U-R heterodimer, followed by the R-R homodimer. This HPLC method was also used to confirm the expected 1:2:1 stoichiometries of homodimer and heterodimer oxime formation, using ten representative uracil and aryl aldehydes from the library (see Supplementary Information, Figure S1). Additional NMR evidence supporting the expected stoichiometries is detailed in the Supplementary Information, Figures S2 and S3.

\section{Synthesis of 2-R Substituted 3, 4-Dihydroxybenzaldehydes and the Corresponding Mixed Oximes with 3}

Aldehyde $\mathbf{4 3}$ was synthesized by removing the methyl groups of the commercially available 3, 4-dimethoxy-6-fluorobenzaldehyde using $\mathrm{BBr}_{3}$ in $\mathrm{CH}_{2} \mathrm{Cl}_{2} 53$. The aldehydes $\mathbf{4 4}$ and $\mathbf{4 5}$ were synthesized by removing the methylene group of the corresponding 2-halogenated piperonal using $\mathrm{AlCl}_{3}$ and $6 \mathrm{~N} \mathrm{HCl}{ }^{54}$. Aldehyde 46 was commercially available. These four aldehydes (43 through $\mathbf{4 6}$ ) were reacted with 6-formyluracil 3 and the $O, O^{\prime}$ -

diaminopropanediol linker using the procedure described above, and the mixed oxime dimer was obtained after HPLC purification.

3-(3)-43: ${ }^{1} \mathrm{H}$ NMR (400 MHz, DMSO-d 6 ): $\delta 8.11(\mathrm{~s}, 1 \mathrm{H}), 7.94(\mathrm{~s}, 1 \mathrm{H}), 7.05(\mathrm{~d}, J=7.2 \mathrm{~Hz}$, $1 \mathrm{H}), 6.58(\mathrm{~d}, J=6.8 \mathrm{~Hz}, 1 \mathrm{H}), 5.77(\mathrm{~s}, 1 \mathrm{H}), 5.10(\mathrm{bs}, \mathrm{H}), 4.28(\mathrm{t}, J=6.8 \mathrm{~Hz}, 2 \mathrm{H}), 4.16(\mathrm{t}, J$ $=6.0 \mathrm{~Hz}, 2 \mathrm{H}), 2.07(\mathrm{~m}, 2 \mathrm{H}) ;{ }^{13} \mathrm{C}$ NMR $\left(125 \mathrm{MHz}, \mathrm{DMSO}-\mathrm{d}_{6}\right): \delta 163.91,155.50,153.09$, $151.08,149.87,149.76,144.65,142.72,142.30,142.21,110.91,110.87,108.62,108.49$, 103.21, 102.96, 101.67, 71.85, 70.06, 28.38; ${ }^{19} \mathrm{~F}$ NMR (DMSO-d 6 ): $\delta-54.33,-54.35,-54.36$, -54.38 ; UV/Vis: $\lambda_{\max } 268 \mathrm{~nm}$; HRMS (m/z): $[\mathrm{M}+\mathrm{Na}]^{+}$calcd for $\mathrm{C}_{15} \mathrm{H}_{15} \mathrm{FN}_{4} \mathrm{O}_{6} \mathrm{Na}, 389.09$; found, 389.09 .

3-(3)-44: ${ }^{1} \mathrm{H}$ NMR (400 MHz, DMSO-d 6 ): $\delta 8.23(\mathrm{~s}, 1 \mathrm{H}), 7.94(\mathrm{~s}, 1 \mathrm{H}), 7.18(\mathrm{~s}, 1 \mathrm{H}), 6.77$ (s, $1 \mathrm{H}), 5.78(\mathrm{~s}, 1 \mathrm{H}), 4.27(\mathrm{t}, J=5.6 \mathrm{~Hz}, 2 \mathrm{H}), 4.16(\mathrm{t}, J=6.0 \mathrm{~Hz}, 2 \mathrm{H}), 2.08(\mathrm{~m}, 2 \mathrm{H}) ;{ }^{13} \mathrm{C} \mathrm{NMR}$ (125 MHz, DMSO-d $\mathrm{d}_{6}$ ): $\delta 163.90,151.08,149.71,145.48,145.16,144.64,142.21,123.00$, 119.09, 116.08, 112.33, 101.67, 71.85, 70.22, 28.37; UV/Vis: $\lambda_{\max } 275 \mathrm{~nm} ; \mathrm{HRMS}$ (m/z): [M $+\mathrm{Na}]^{+}$calcd for $\mathrm{C}_{15} \mathrm{H}_{15} \mathrm{ClN}_{4} \mathrm{O}_{6} \mathrm{Na}, 405.06$; found, 405.06.

3-(3)-45: ${ }^{1} \mathrm{H}$ NMR (400 MHz, DMSO-d 6 ): $\delta 8.18$ (s, $\left.1 \mathrm{H}\right), 7.94$ (s, $\left.1 \mathrm{H}\right), 7.19$ (s, $\left.1 \mathrm{H}\right), 6.93$ (s, $1 \mathrm{H}), 5.78(\mathrm{~s}, 1 \mathrm{H}), 4.27(\mathrm{t}, J=6.4 \mathrm{~Hz}, 2 \mathrm{H}), 4.16(\mathrm{t}, J=6.4 \mathrm{~Hz}, 2 \mathrm{H}), 2.08(\mathrm{~m}, 2 \mathrm{H}) ;{ }^{13} \mathrm{C}$ NMR $\left(125 \mathrm{MHz}\right.$, DMSO-d $\left.{ }_{6}\right): \delta 163.91,151.10,150.07,147.41,146.02,144.66,142.22,120.58$, $119.15,112.89,112.29,101.69,71.86,70.24,28.38$; UV/Vis: $\lambda_{\max } 278 \mathrm{~nm} ; \mathrm{HRMS}$ (m/z): [M $+\mathrm{Na}]^{+}$calcd for $\mathrm{C}_{15} \mathrm{H}_{15} \mathrm{BrN}_{4} \mathrm{O}_{6} \mathrm{Na}, 449.01$; found, 449.01 .

3-(3)-46: ${ }^{1} \mathrm{H}$ NMR (400 MHz, DMSO-d 6 ): $\delta 8.56$ (d, $\left.J=1.2 \mathrm{~Hz}, 1 \mathrm{H}\right), 7.95(\mathrm{~s}, 1 \mathrm{H}), 7.37$ (s, $1 \mathrm{H}), 6.74(\mathrm{~s}, 1 \mathrm{H}), 6.26$ (bs, H), $5.78(\mathrm{~d}, J=1.2 \mathrm{~Hz}, 1 \mathrm{H}), 4.28$ (t, $J=6.0 \mathrm{~Hz}, 2 \mathrm{H}), 4.16$ (t, $J$ $=6.0 \mathrm{~Hz}, 2 \mathrm{H}), 2.09(\mathrm{~m}, 2 \mathrm{H}) ;{ }^{13} \mathrm{C}$ NMR $\left(125 \mathrm{MHz}, \mathrm{DMSO}_{-} \mathrm{d}_{6}\right): \delta 163.88,160.27,151.05$, 148.62, 148.00, 144.62, 142.22, 133.36, 122.38, 113.80, 109.23, 101.73, 71.85, 70.07, 28.39; UV/Vis: $\lambda_{\max } 269 \mathrm{~nm}$; HRMS (m/z): [M+H] $]^{+}$calcd for $\mathrm{C}_{15} \mathrm{H}_{16} \mathrm{~N}_{5} \mathrm{O}_{8}, 394.10$; found, 394.10. 


\section{Synthesis of Methyl Oxime Derivatives of 1-3, 13 and 27}

The $O$-methyl oxime of 3,4-dihydroxybenzaldehyde (47) is known, and was synthesized using 13 and $O$-methylhydroxylamine hydrochloride ${ }^{55}$. $O$-methyloximes $48-51$ were made using a similar method.

48: To a solution of 27 (308 mg, $2.0 \mathrm{mmol})$ in $4.0 \mathrm{ml}$ of EtOH- $\mathrm{H}_{2} \mathrm{O}-\mathrm{THF}(0.45 / 0.3 / 0.25)$ were added sodium acetate $(264 \mathrm{mg}$ ) and $O$-methylhydroxylamine hydrochloride $(183 \mathrm{mg})$, and the solution was stirred at room temperature for overnight. The solvents were removed in vacuo and the residue was extracted with chloroform three times. The combined organic layers were dried over anhydrous $\mathrm{MgSO}_{4}$ and concentrated in vacuo. The residue was purified by silica gel column chromatography (EtOAc/hexanes) to give product $347 \mathrm{mg}$ in $95 \%$ yield. ${ }^{1} \mathrm{H}$ NMR (400 MHz, DMSO-d 6 ): $\delta 9.38(\mathrm{~s}, 1 \mathrm{H}), 9.21(\mathrm{~s}, 1 \mathrm{H}), 8.52(\mathrm{~s}, 1 \mathrm{H}), 8.18(\mathrm{~s}, 1 \mathrm{H}), 6.88(\mathrm{~s}, 1 \mathrm{H})$, $6.30(\mathrm{~s}, 1 \mathrm{H}), 3.80(\mathrm{~s}, 3 \mathrm{H}) ;{ }^{13} \mathrm{C}$ NMR $\left(125 \mathrm{MHz}, \mathrm{DMSO}_{-} \mathrm{d}_{6}\right): \delta 150.17,148.88,146.52,138.61$, 112.51, 107.77, 103.46, 61.28; UV/Vis: $\lambda_{\max } 239,274 \mathrm{~nm}$; HRMS (m/z): $[\mathrm{M}+\mathrm{H}]^{+}$calcd for $\mathrm{C}_{8} \mathrm{H}_{10} \mathrm{NO}_{4}, 184.06$; found, 184.06 .

49: To a solution of $\mathbf{1}(10.8 \mathrm{mg}, 0.063 \mathrm{mmol})$ in hot $\mathrm{DMF}(0.5 \mathrm{ml})$, were added sodium acetate $(5.2 \mathrm{mg}, 0.063 \mathrm{mmol})$ solution in water $(0.1 \mathrm{ml})$ and $O$-methylhydroxylamine hydrochloride (5.3 $\mathrm{mg}, 0.063 \mathrm{mmol}$ ), and the solution was stirred at room temperature for overnight. The solvents were removed in vacuo and the residue was purified by column chromatography using $10-15 \%$ (v/v) methanol in $\mathrm{CH}_{2} \mathrm{Cl}_{2}$, resulting in $90 \%$ yield (10.3 mg 50/50 mixture of trans and cis geometric isomers). ${ }^{1} \mathrm{H}$ NMR $(400 \mathrm{MHz}$, chloroform-d): $\delta 9.56(\mathrm{~s}, 1 \mathrm{H}), 7.43(\mathrm{t}, J=$ $5.2 \mathrm{~Hz}, 0.5 \mathrm{H}), 7.20(\mathrm{~m}, 1 \mathrm{H}), 6.80(\mathrm{t}, J=4.4 \mathrm{~Hz}, 0.5 \mathrm{H}), 5.78(\mathrm{~m}, 1 \mathrm{H}), 4.55(\mathrm{~d}, J=4.4 \mathrm{~Hz}, 1$ $\mathrm{H}), 4.48(\mathrm{~d}, J=5.6 \mathrm{~Hz}, 1 \mathrm{H}), 3.94(\mathrm{~s}, 1.5 \mathrm{H}), 3.87(\mathrm{~s}, 1.5 \mathrm{H}) ;{ }^{13} \mathrm{C}$ NMR $(100 \mathrm{MHz}$, DMSO$\left.\mathrm{d}_{6}\right)$ : $\delta 163.92,163.87,151.06,150.99,144.72,144.54,143.93,143.53,103.14,102.97,62.68$, 62.37, 46.52, 43.76. UV/Vis: $\lambda_{\max } 263 \mathrm{~nm} ; \mathrm{HRMS}(\mathrm{m} / \mathrm{z})$ : $[\mathrm{M}+\mathrm{H}]^{+}$calcd for $\mathrm{C}_{7} \mathrm{H}_{10} \mathrm{~N}_{3} \mathrm{O}_{3}$, 184.07; found, 184.07 .

50: To a solution of $2(70 \mathrm{mg}, 0.5 \mathrm{mmol})$ in hot DMF $(1 \mathrm{ml})$, were added sodium acetate (41 $\mathrm{mg}, 0.5 \mathrm{mmol})$ solution in water $(0.5 \mathrm{ml})$ and $O$-methylhydroxylamine hydrochloride $(42 \mathrm{mg}$, $0.5 \mathrm{mmol}$ ), and the solution was stirred at room temperature for $4 \mathrm{hrs}$. The solvents were removed in vacuo and the residue was collected by filtration and washed with cold water $2 \times$ $1 \mathrm{ml}$, resulting in $76 \%$ yield (70 mg 87/13 mixture of trans and cis geometric isomers). ${ }^{1} \mathrm{H}$ NMR (400 MHz, DMSO-d ${ }_{6}$ ): $\delta 11.40$ (bs, $\left.2 \mathrm{H}\right), 8.52$ (s, $\left.0.13 \mathrm{H}\right), 7.87$ (s, $\left.0.87 \mathrm{H}\right), 7.74$ (s, 0.87 $\mathrm{H}), 7.29(\mathrm{~s}, 0.13 \mathrm{H}), 3.89(\mathrm{~s}, 0.39 \mathrm{H}), 3.80(\mathrm{~s}, 2.61 \mathrm{H}) ;{ }^{13} \mathrm{C}$ NMR $\left(100 \mathrm{MHz}, \mathrm{DMSO}-\mathrm{d}_{6}\right): \delta$ 162.98, 162.36, 150.80, 150.27, 146.08, 142.26, 140.09, 137.31, 104.41, 103.43, 62.32, 61.44; UV/Vis: $\lambda_{\max } 288 \mathrm{~nm}$; HRMS (m/z): [M+H] ${ }^{+}$calcd for $\mathrm{C}_{6} \mathrm{H}_{8} \mathrm{~N}_{3} \mathrm{O}_{3}, 170.06$; found, 170.06 .

51: To a solution of $\mathbf{3}(79 \mathrm{mg}, 0.5 \mathrm{mmol})$ in hot DMF ( $2.0 \mathrm{ml})$, were added sodium acetate (46 $\mathrm{mg}, 0.5 \mathrm{mmol})$ solution in water $(0.5 \mathrm{ml})$ and $O$-methylhydroxylamine hydrochloride $(46 \mathrm{mg}$, $0.5 \mathrm{mmol}$ ), and the solution was stirred at $50^{\circ} \mathrm{C}$ for $4 \mathrm{~h}$. The solvents were removed in vacuo and the residue was washed by cold water. After the filtration, product was obtained in $62 \%$ yield (53 mg). ${ }^{1} \mathrm{H}$ NMR (400 MHz, DMSO-d 6 ): $\delta 11.18(\mathrm{~s}, 1 \mathrm{H}), 10.77(\mathrm{~s}, 1 \mathrm{H}), 7.91(\mathrm{~s}, 1 \mathrm{H})$, $5.77(\mathrm{~s}, 1 \mathrm{H}), 3.96(\mathrm{~s}, 3 \mathrm{H}) ;{ }^{13} \mathrm{C}$ NMR $\left(125 \mathrm{MHz}, \mathrm{DMSO}_{-} \mathrm{d}_{6}\right): \delta 163.87,151.02,144.51,142.17$, 101.41, 62.84; UV/Vis: $\lambda_{\max } 292 \mathrm{~nm}$; HRMS (m/z): $[\mathrm{M}+\mathrm{Na}]^{+}$calcd for $\mathrm{C}_{6} \mathrm{H}_{7} \mathrm{~N}_{3} \mathrm{O}_{3} \mathrm{Na}, 192.04$; found, 192.04 .

\section{High-Throughput Inhibitor Screening}

The substrate in this HTS assay was synthesized using standard phosphoramidite DNA solid phase chemistry using reagents purchased from Glen Research. The DNA was purified using anion exchange chromatography followed by desalting using reversed phase methods. The sequence and size was confirmed using analytical denaturing polyacrylamide gel 
electrophoresis and MALDI-MS. The substrate is a double-stranded 14-mer DNA containing nine U.A base pairs (5'-FAM-GCA CUU AAG AAU UG:3'-DABSYL-CA AUU CUU AAG UGC). The UNG HTS assay is performed as follows. To a 96-well microtiter plate was added $5 \mu \mathrm{L} 2 \mathrm{mM}$ total compound in DMSO, followed by $75 \mu \mathrm{L} 33.3 \mathrm{pM}$ human UNG in reaction buffer ( $10 \mathrm{mM}$ Tris. $\mathrm{HCl}, \mathrm{pH} 8.0,20 \mathrm{mM} \mathrm{NaCl}, 7.5 \mathrm{mM} \mathrm{MgCl}_{2}, 0.002 \%$ brij-35). The reactions were initiated by the addition of $20 \mu \mathrm{L} 250 \mathrm{nM}$ molecular beacon substrate in reaction buffer. The plates are incubated at ambient temperature in a fluorescence plate reader for 30 minutes, and the progress of the reaction was monitored every five minutes (Ex. $485 \mathrm{~nm} / \mathrm{Em} .520 \mathrm{~nm}$ ). The final concentrations of the reagents in the assay are $10 \mathrm{mM}$ Tris. $\mathrm{HCl}, \mathrm{pH} 8.0,20 \mathrm{mM} \mathrm{NaCl}$, $7.5 \mathrm{mM} \mathrm{MgCl}_{2}, 0.002 \%$ Brij-35, $25 \mathrm{pM}$ human UNG, $50 \mathrm{nM}$ molecular beacon substrate, 100 $\mu \mathrm{M}$ total compound, $5 \% \mathrm{DMSO}$. The $\mathrm{MgCl}_{2}$ is essential to increase the stability of the doublestranded DNA substrate, and thus decrease the initial fluorescence of the molecular beacon and increase the maximum signal of the assay. Addition of Brij-35, a non-ionic detergent, is essential to stabilize human UNG at the low concentration used in this assay. A similar assay has been described by Maksimenko et al. that utilizes a 39-mer hairpin DNA ${ }^{56}$. However, the synthesis and purification of this more complex substrate proceeds with low efficiency, and requires higher temperature to induce strand separation (Krosky and Stivers, unpublished). In contrast, the 14 mer double-stranded molecular beacon is routine, and allows screening to be performed conveniently at room temperature.

\section{Mechanism of Inhibition}

The substrate used in mechanism of inhibition studies was a modified DNA hairpin where the two strands described above are connected by a hexa-polyethylene glycol linker (PEG-U9). This substrate was easier to synthesize and purify than an all DNA hairpin, and unlike the double stranded DNA substrate, does not require $\mathrm{MgCl}_{2}$ to achieve minimum fluorescence. To a 96-well plate was added $5 \mu \mathrm{L}$ compound in DMSO, followed by $75 \mu \mathrm{L}$ PEG-U9 hairpin in reaction buffer (20 mM Tris HCl, pH 8.0, $50 \mathrm{mM} \mathrm{KCl}, 0.2 \mathrm{mM} \mathrm{MgCl}_{2}, 0.002 \%$ Brij-35, 1 $\mathrm{mM}$ DTT). Eight different DNA concentrations were used in the range of 62.5 to $2000 \mathrm{nM}$. Reactions were initiated by the addition of $20 \mu \mathrm{L} 0.5 \mathrm{nM}$ human UNG in reaction buffer. The final concentrations of reagents in the assay are $20 \mathrm{mM}$ Tris $\mathrm{HCl}, \mathrm{pH} 8.0,50 \mathrm{mM} \mathrm{KCl}, 0.2 \mathrm{mM}$ $\mathrm{MgCl}_{2}, 0.002 \%$ Brij-35, 1 mM DTT, 5\% DMSO, $0.1 \mathrm{nM}$ human UNG, 62.5-2000 nM PEGU9 hairpin DNA, and variable amounts of inhibitor. The plates were incubated at ambient temperature in a fluorescence plate reader for 60 minutes, and the progress of each reaction was monitored every five minutes (Ex. $485 \mathrm{~nm} / \mathrm{Em} .520 \mathrm{~nm}$ ). Afterwards, $E$. coli UNG was added to each well to drive the reactions to completion, and the overall change in fluorescence values were measured. These values were used to convert initial velocities from units of fluorescence units/s to [product]/s. Mechanisms of inhibition and their corresponding inhibitor dissociation constants were determined by Lineweaver-Burk slope and intercept replot analysis and by computational simulations of the initial velocity against inhibitor concentration data using Dynafit v.3.28 (see Supplemental Information)

\section{Conclusions}

We have developed an efficient strategy to develop small molecule inhibitors of UNG that have the potential for activity in cell culture or in vivo. The method is quite general and could be adapted to target other enzymes that bind extrahelical bases or free nucleosides. Two future targets of the current uracil mixed oxime library would be the essential bacterial enzyme deoxyuridine nucleotidylhydrolase which converts dUTP to dUMP $23,57-60$, and human thymidine phosphorylase, an enzyme implicated in vascularization of tumors ${ }^{61}$. Such inhibitors could serve as useful tools to study the life cycle of pathogenic human viruses, the biology of uracil base excision repair in normal cell lines and tissues, and mechanisms of tumor vascularization. 


\section{Supplementary Material}

Refer to Web version on PubMed Central for supplementary material.

\section{Acknowledgements}

This work was supported by NIH grant GM56834-10 to J.T.S. D.J.K was supported by the DOD Breast Cancer Research Program (DAMD17-03-1-1251).

\section{References}

1. Lindahl T, Wood RD. Science 1999;286:1897-1905. [PubMed: 10583946]

2. Di Noia J, Neuberger MS. Nature 2002;419:43-48. [PubMed: 12214226]

3. Imai K, Slupphaug G, Lee WI, Revy P, Nonoyama S, Catalan N, Yel L, Forveille M, Kavli B, Krokan HE, Ochs HD, Fischer A, Durandy A. Nature Immunol 2003;4:1023-1028. [PubMed: 12958596]

4. Storb U, Stavnezer J. Curr Biol 2002;12:R725-727. [PubMed: 12419200]

5. Chen R, Wang H, Mansky LM. J Gen Virol 2002;83:2339-2345. [PubMed: 12237414]

6. Prichard MN, Duke GM, Mocarski ES. J Virol 1996;70:3018-3025. [PubMed: 8627778]

7. De Silva FS, Moss B. J Virol 2003;77:159-166. [PubMed: 12477821]

8. Stuart DT, Upton C, Higman MA, Niles EG, McFadden G. J Virol 1993;67:2503-2512. [PubMed: 8474156]

9. Priet S, Gros N, Navarro JM, Boretto J, Canard B, Querat G, Sire J. Mol Cell 2005;17:479-490. [PubMed: 15721252]

10. Ladner RD. Curr Protein Pept Sci 2001;2:361-370. [PubMed: 12374095]

11. Tinkelenberg BA, Hansbury MJ, Ladner RD. Cancer Res 2002;62:4909-4915. [PubMed: 12208740]

12. Stivers JT, Drohat AC. Arch Biochem Biophys 2001;396:1-9. [PubMed: 11716455]

13. Bianchet MA, Seiple LA, Jiang YL, Ichikawa Y, Amzel LM, Stivers JT. Biochemistry 2003;42:12455-12460. [PubMed: 14580190]

14. Jiang YL, Cao C, Stivers JT, Song F, Ichikawa Y. Bioorg Chem 2004;32:244-262. [PubMed: 15210339]

15. Krosky DJ, Song F, Stivers JT. Biochemistry 2005;44:5949-5959. [PubMed: 15835884]

16. Sekino Y, Bruner SD, Verdine GL. J Biol Chem 2000;275:36506-36508. [PubMed: 11084051]

17. Putnam CD, Shroyer MJN, Lundquist AJ, Mol CD, Arvai AS, Mosbaugh DW, Tainer JA. J Mol Biol 1999;287:331-346. [PubMed: 10080896]

18. Bouhamdan M, Benichou S, Rey F, Navarro JM, Agostini I, Spire B, Camonis J, Slupphaug G, Vigne R, Benarous R, Sire J. J Virol 1996;70:697-704. [PubMed: 8551605]

19. BouHamdan M, Xue Y, Baudat Y, Hu B, Sire J, Pomerantz RJ, Duan LX. J Biol Chem 1998;273:8009-8016. [PubMed: 9525900]

20. Chen R, Le Rouzic E, Kearney JA, Mansky LM, Benichou S. J Biol Chem 2004;279:28419-28425. [PubMed: 15096517]

21. Klarmann GJ, Chen X, North TW, Preston BD. J Biol Chem 2003;278:7902-7909. [PubMed: 12458216]

22. Mansky LM, Preveral S, Selig L, Benarous R, Benichou S. J Virol 2000;74:7039-7047. [PubMed: 10888643]

23. Payne SL, Elder JH. Curr Protein Pept Sci 2001;2:381-388. [PubMed: 12374097]

24. Selig L, Benichou S, Rogel ME, Wu LI, Vodicka MA, Sire J, Benarous R, Emerman M. J Virol 1997;71:4842-4846. [PubMed: 9151883]

25. Willetts KE, Rey F, Agostini I, Navarro JM, Baudat Y, Vigne R, Sire J. J Virol 1999;73:1682-1688. [PubMed: 9882380]

26. Mansky LM, Le Rouzic E, Benichou S, Gajary LC. J Virol 2003;77:2071-2080. [PubMed: 12525642]

27. Miller RJ, Cairns JS, Bridges S, Sarver N. J Virol 2000;74:7187-7195. [PubMed: 10906172] 
28. Elder RT, Zhu X, Priet S, Chen M, Yu M, Navarro JM, Sire J, Zhao Y. Biochem Biophys Res Commun 2003;306:693-700. [PubMed: 12810074]

29. Lau A, Swinbank KM, Ahmed PS, Taylor DL, Jackson SP, Smith GC, O’Connor MJ. Nature Cell Biol 2005;7:493-500. [PubMed: 15834407]

30. Nilsen H, Rosewell I, Robins P, Skjelbred CF, Andersen S, Slupphaug G, Daly G, Krokan HE, Lindahl T, Barnes DE. Mol Cell 2000;5:1059-1065. [PubMed: 10912000]

31. Drohat AC, Stivers JT. Biochemistry 2000;39:11865-11875. [PubMed: 11009598]

32. Drohat AC, Stivers JT. J Am Chem Soc 2000:1840-1841.

33. Maly DJ, Choong IC, Ellman JA. Proc Natl Acad Sci U S A 2000;97:2419-2424. [PubMed: 10716979]

34. Winans KA, Bertozzi CR. Chem Biol 2002;9:113-129. [PubMed: 11841944]

35. Kwon K, Nagarajan R, Stivers JT. Biochemistry 2004;43:14994-15004. [PubMed: 15554707]

36. Segel, IH. Enzyme Kinetics. John Wiley \& Sons, Inc.; New York: 1993.

37. Kuzmic P. Anal Biochem 1996;237:260-273. [PubMed: 8660575]

38. Jiang YL, Kwon K, Stivers JT. J Biol Chem 2001;276:42347-42354. [PubMed: 11551943]

39. Jiang YL, Song F, Stivers JT. Biochemistry 2002;41:11248-11254. [PubMed: 12220190]

40. Jiang YL, Stivers JT. Biochemistry 2002;41:11236-11247. [PubMed: 12220189]

41. Cao C, Jiang YL, Stivers JT, Song F. Nat Struct Mol Biol 2004;11:1230-1236. [PubMed: 15558051]

42. Jiang YL, McDowell L, Poliks B, Studelska D, Cao C, Potter GS, Schaefer J, Song F, Stivers JT. Biochemistry 2004;43:15429-15438. [PubMed: 15581354]

43. Savva R, McAuley-Hecht K, Brown T, Pearl L. Nature 1995;373:487-493. [PubMed: 7845459]

44. Banerjee A, Yang W, Karplus M, Verdine GL. Nature 2005;434:612-618. [PubMed: 15800616]

45. Kavli B, Slupphaug G, Mol CD, Arvai AS, Peterson SB, Tainer JA, Krokan HE. EMBO J 1996;15:3442-3447. [PubMed: 8670846]

46. Mol CD, Arvai AS, Slupphaug G, Kavli B, Alseth I, Krokan HE, Tainer JA. Cell 1995;80:869-878. [PubMed: 7697717]

47. Kwon K, Jiang Y, Stivers J. Chem Biol 2003;10:1-20. [PubMed: 12573691]

48. Page MI, Jencks WP. Proc Natl Acad Sci U S A 1971;68:1678-1683. [PubMed: 5288752]

49. Jencks, WP. Catalysis in Chemistry and Enzmology. Dover Publications, Inc.; New York: 1987. Binding Energy, Specificity, and Enzymic Catalysis: The Circe Effect; p. 615-807.

50. The uracil N1-acetaldehyde O-methyl oxime (49) showed undetectable inhibition $\left(K_{\mathrm{c}}>10 \mathrm{mM}\right.$.

51. Kung PP, Bharadwaj R, Fraser AS, Cook DR, Kawasaki AM, Cook PD. J Org Chem 1998;63:18461852.

52. Weiss RH, Furfine E, Hausleden E, Dixon DW. J Org Chem 1984;49:4969-4972.

53. Kirk KL, Cantacuzene D, Nimitkitpaisan Y, Mcculloh D, Padgett WL, Daly JW, Creveling CR. J Med Chem 1979;22:1493-1497. [PubMed: 231654]

54. Reitz A, Avery MA, Verlander MS, Goodman M. J Org Chem 1981;46:4859-4863.

55. Watanabe T, Suzuki T, Umezawa Y, Takeuchi T, Otsuka M, Umezawa K. Tetrahedron 2000;56:741752.

56. Maksimenko A, Ishchenko AA, Sanz G, Laval J, Elder RH, Saparbaev MK. Biochem Biophys Res Commun 2004;319:240-246. [PubMed: 15158468]

57. Grasser FA, Romeike BF, Niedobitek G, Nicholls J, Kremmer E. Curr Protein Pept Sci 2001;2:349_ 360. [PubMed: 12369931]

58. Hidalgo-Zarco F, Gonzalez-Pazanowska D. Curr Protein Pept Sci 2001;2:389-397. [PubMed: 12374098]

59. Studebaker AW, Balendiran GK, Williams MV. Curr Protein Pept Sci 2001;2:371-379. [PubMed: 12374096]

60. Williams MV. Virology 1988;166:262-264. [PubMed: 2842952]

61. Toi M, Atiqur Rahman M, Bando H, Chow LW. Lancet Oncol 2005;6:158-166. [PubMed: 15737832]

$J$ Am Chem Soc. Author manuscript; available in PMC 2008 August 26. 

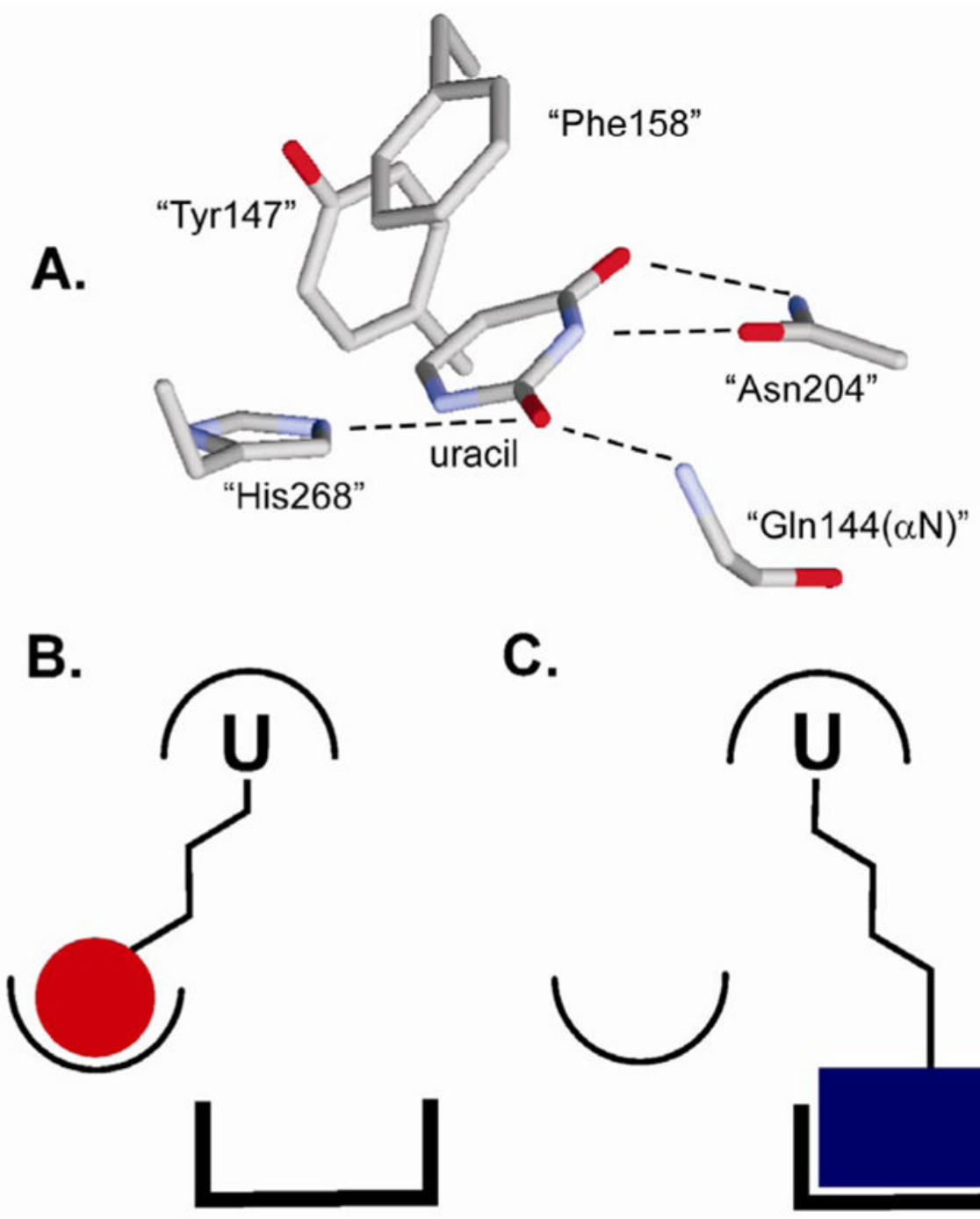

C.

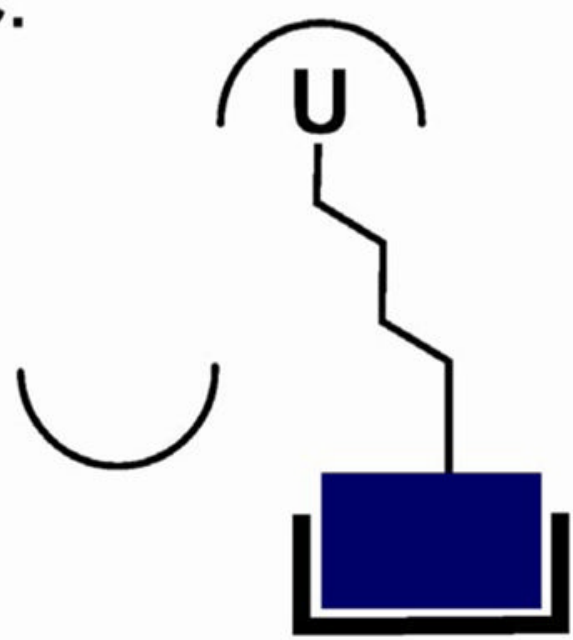

Figure 1.

Extrahelical binding of uracil to the UNG active site and the general strategy for uracil-directed ligand tethering. (A) Structure of UNG bound to uracil (pdb code 2eug). The residue numbering is for the human enzyme. (B) and (C) The uracil ligand (U) that targets the UDG active site is covalently tethered to two different ligands that can interact with distinct binding surfaces near the active site. 
A.

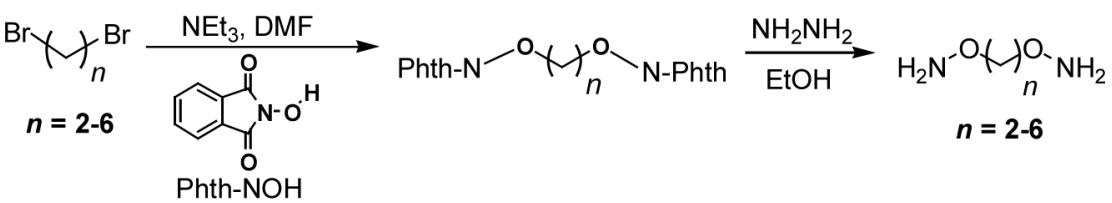

B.

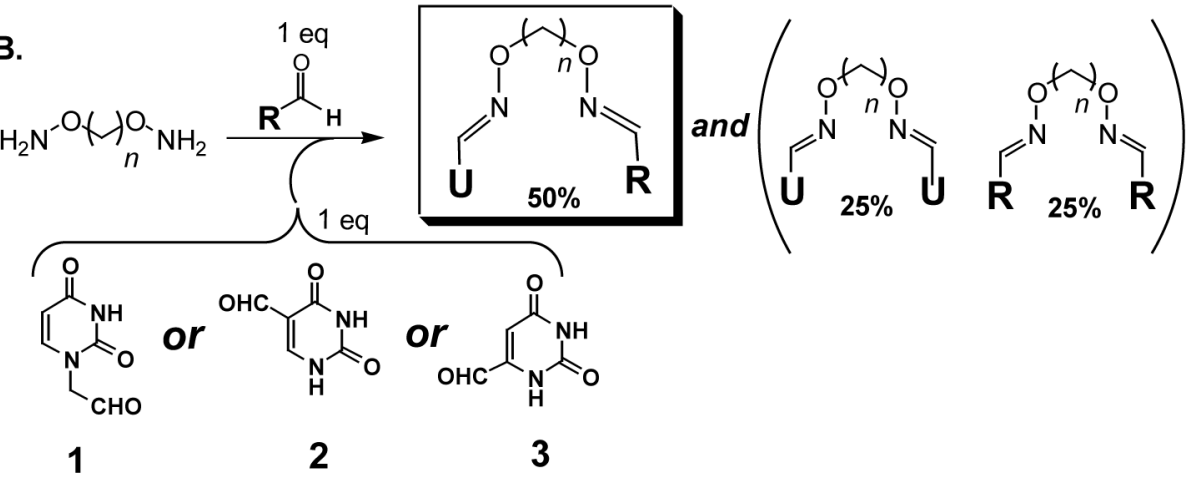

Figure 2.

Synthesis of oxime libraries based on uracil and RCHO. (A) Synthesis of diaminoalkanediol tethers of variable length. (B) Construction of the uracil-oxime library based on the uracil aldehydes (1-3) and a series of aldehyde compounds (RCHO). The products consist of a 1:2:1 mixture of the heterodimer $\left(U^{\wedge} R\right)$, and the two homodimers $\left(U^{\wedge} U\right.$ and $\left.R^{\wedge} R\right)$ connected via alkane linkers of lengths 2-6. One equivalent of total diaminoalkanediol is added to each reaction. Each linker length is present at one-fifth of the total concentration. 

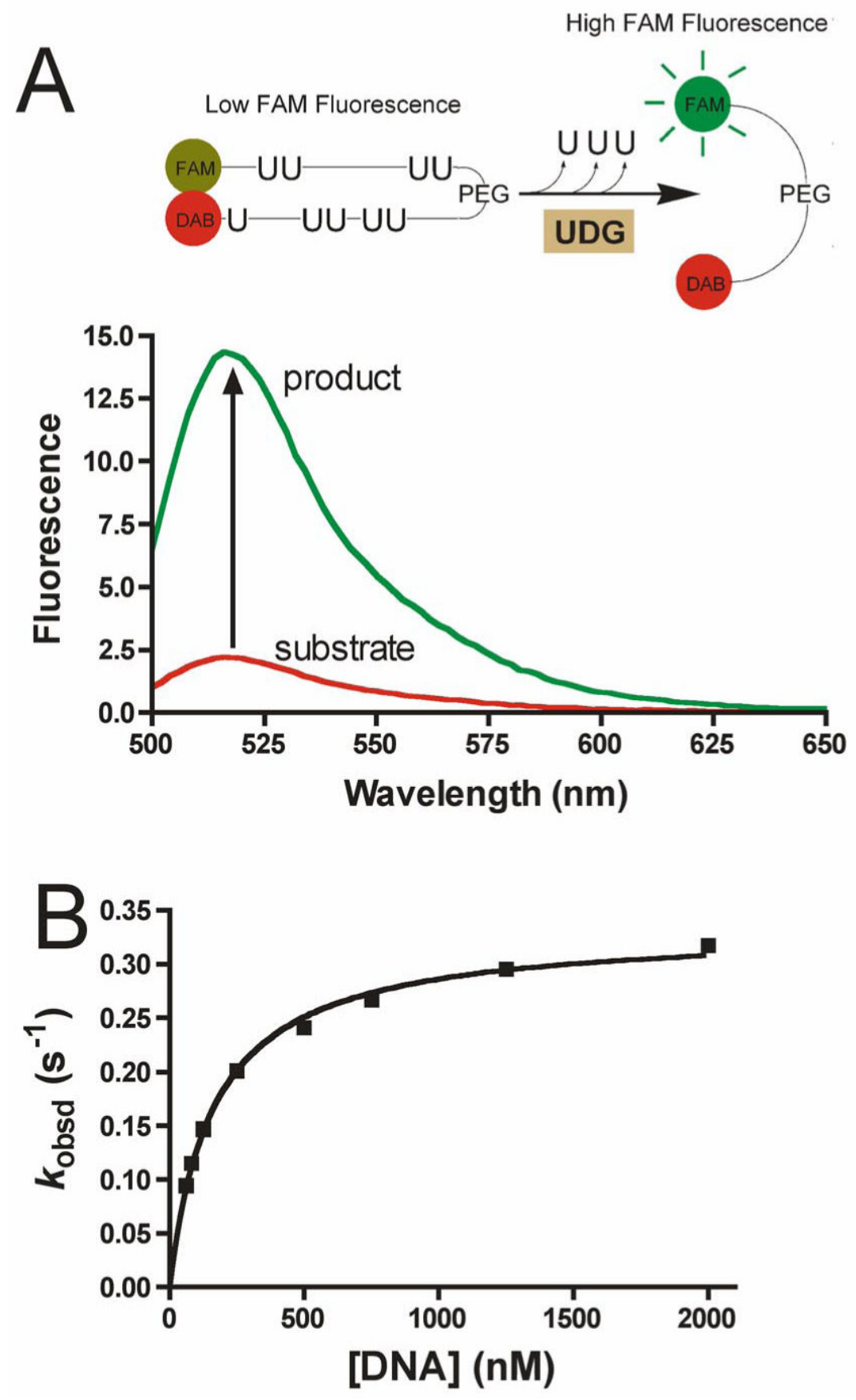

Figure 3.

High-throughput (HTP) UDG kinetic assay. (A) The HTP assay relies on molecular beacon technology. Excision of multiple uracil bases by the enzyme destabilizes the hairpin structure thereby releasing the 5' FAM fluorophore from the quenching effects of the $3^{\prime}$ dabsyl group. (B) Steady-state kinetic analysis of the hUDG reaction using the molecular beacon hairpin substrate. 

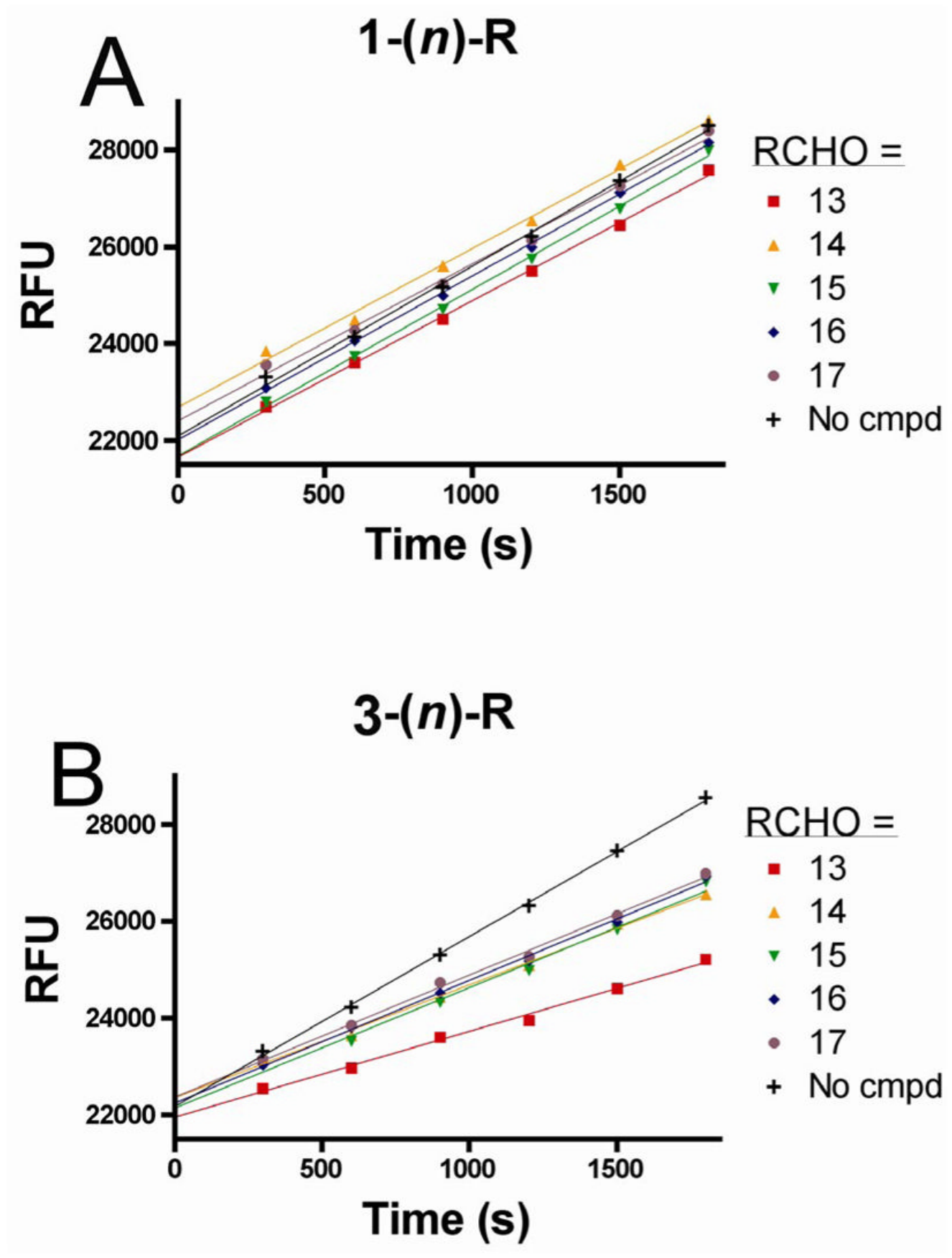

Figure 4.

Representative HTP screening results using the molecular beacon substrate. (A) Screen of oxime dimer mixtures derived from uracil aldehyde 1 and aryl aldehydes 13-17. No inhibition was observed for any oxime derived from 1 regardless of linker length $(n)$. (B) Screen of oxime dimer mixtures derived from uracil aldehyde $\mathbf{3}$ and aryl aldehydes 13-17. The mixed oxime derived from 3 and $\mathbf{1 3}$ shows significant inhibition and this derivative was further optimized. For 14-17, the observed inhibition represents that from the 3-3 homodimers that are present in the mixtures. 


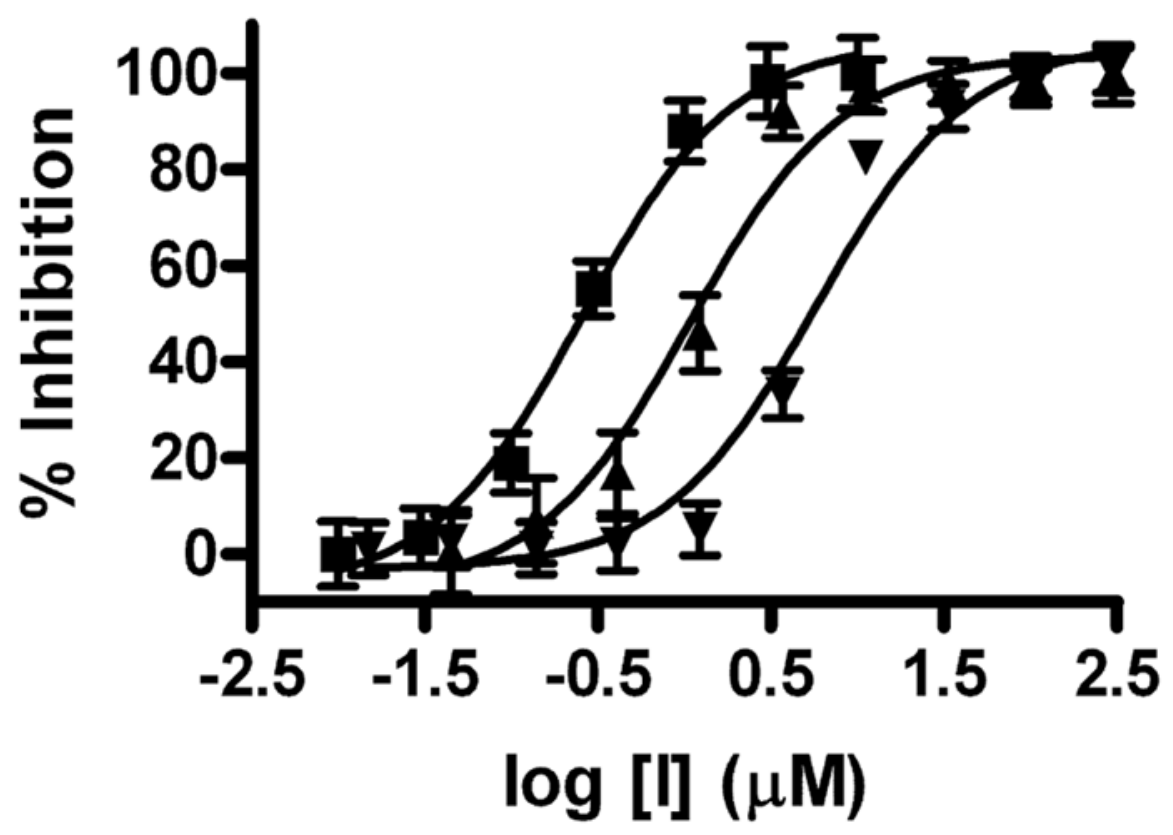

Figure 5.

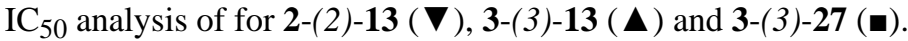



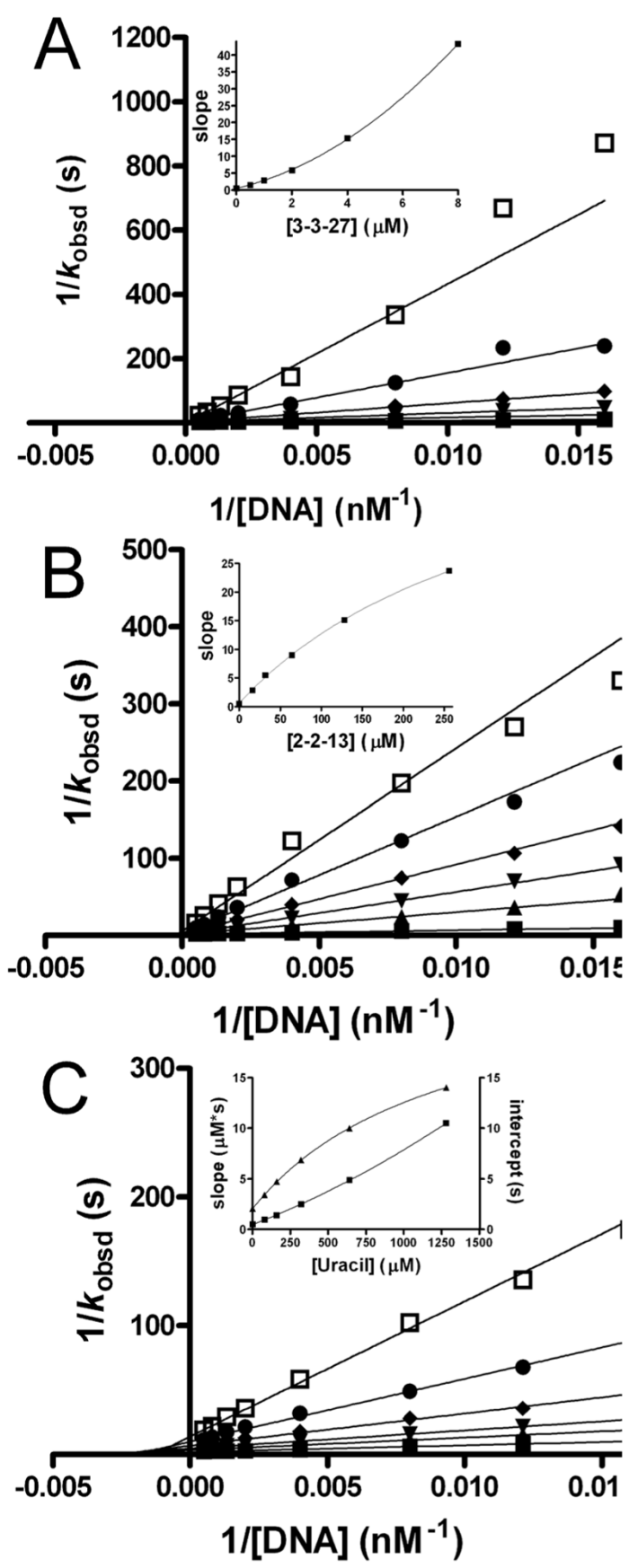

Figure 6.

Mode of inhibition analysis. Double reciprocal plots and secondary slope and intercept replots for inhibition by increasing concentrations of (A) 3-(3)-27, (B) 2-(2)-13, and (C) uracil. Slope and intercept effects in the inset to $(\mathrm{C})$ are shown as squares and triangles, respectively. 


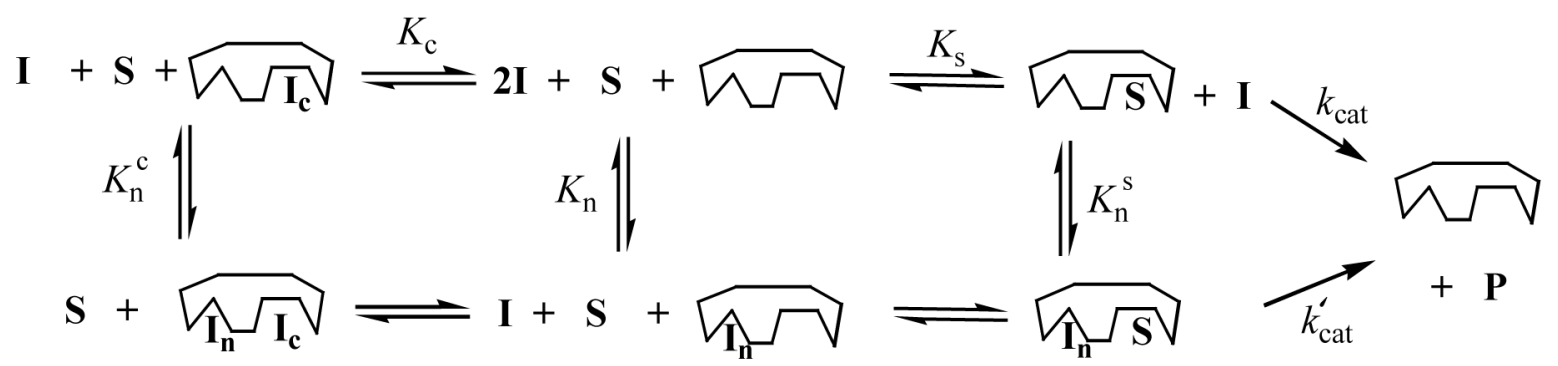

Scheme 1.

Inhibition Mechanisms for 3-(3)-27 and 2-(2)-13 and Uracil ${ }^{\mathrm{a}}$

a'Only 3-(3)-27, 2-(2)-13 and uracil have mechanisms that include the $k_{\text {cat }}$ 'step. The mechanism for 3-(3)-and uracil do not include the equilibrium constant $K_{\mathrm{n}}$, and the mechanism for 2-

(2)-13 does not include the equilibria $K_{\mathrm{c}}$ or $K_{\mathrm{n}}{ }^{\mathrm{c}}$. 


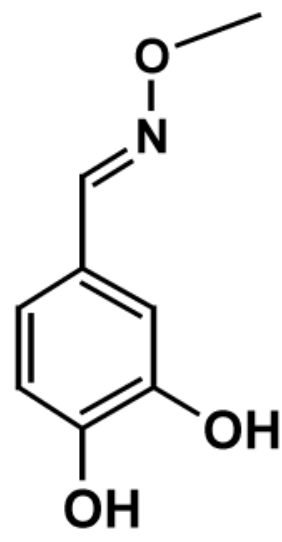

47

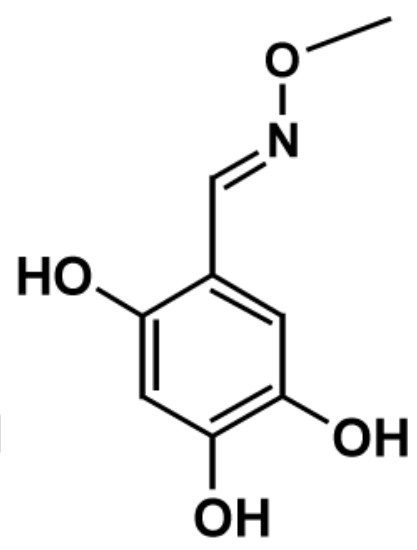

48

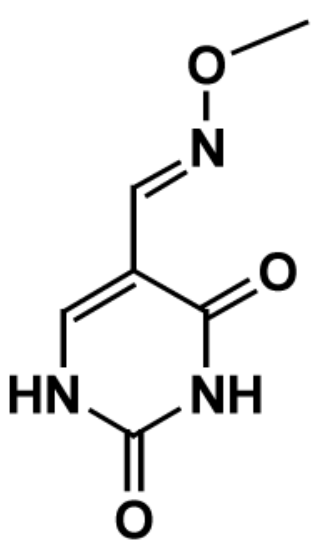

50

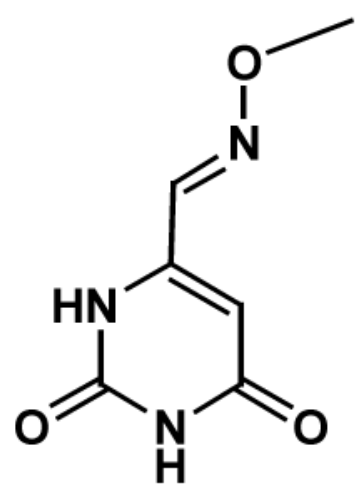

51

Scheme 2.

$O$-methyl Oxime Derivatives of the Aldehyde Binding Elements of 2-(2)-13 and 3-(3)-27 
<smiles>O=c1[nH]cc(/C=N/OCCO/N=C/c2ccc(O)c(O)c2)c(=O)[nH]1</smiles>
2-(2)-13<smiles>O=c1cc(/C=N/OCCCO/N=C/c2ccc(O)c(O)c2)[nH]c(=O)[nH]1</smiles>

Chart 1.

Heterodimer Oximes Identified from Deconvolution of Active Mixtures 
Table 1

Structures of active heterodimers and dependence of inhibition on linker Length ${ }^{a}$

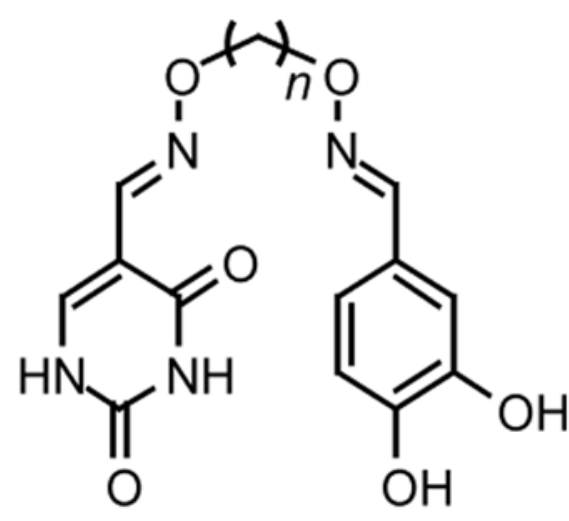

$\mathrm{OH}$<smiles>CC(C)(C)ON=Cc1ccc(O)c(O)c1</smiles>

3-(n)-13

Linker length $(n)$

\% Inhibition

\begin{tabular}{lll}
\hline $\mathbf{2}-(n)-\mathbf{1 3}$ & 2 & 50 \\
& 3 & 40 \\
& 4 & 20 \\
$3-(n)-\mathbf{1 3}$ & 5 & 20 \\
& 6 & 15 \\
& 2 & 57 \\
& 3 & 100 \\
& 4 & 51 \\
& 5 & 48 \\
& 6 & 48
\end{tabular}

${ }^{a}$ Reactions were performed in the presence of $100 \mu \mathrm{M}$ oxime mixture and $50 \mathrm{nM}$ substrate concentration. 
Table 2

Inhibitory activity for structural variants of 3-(3)-27

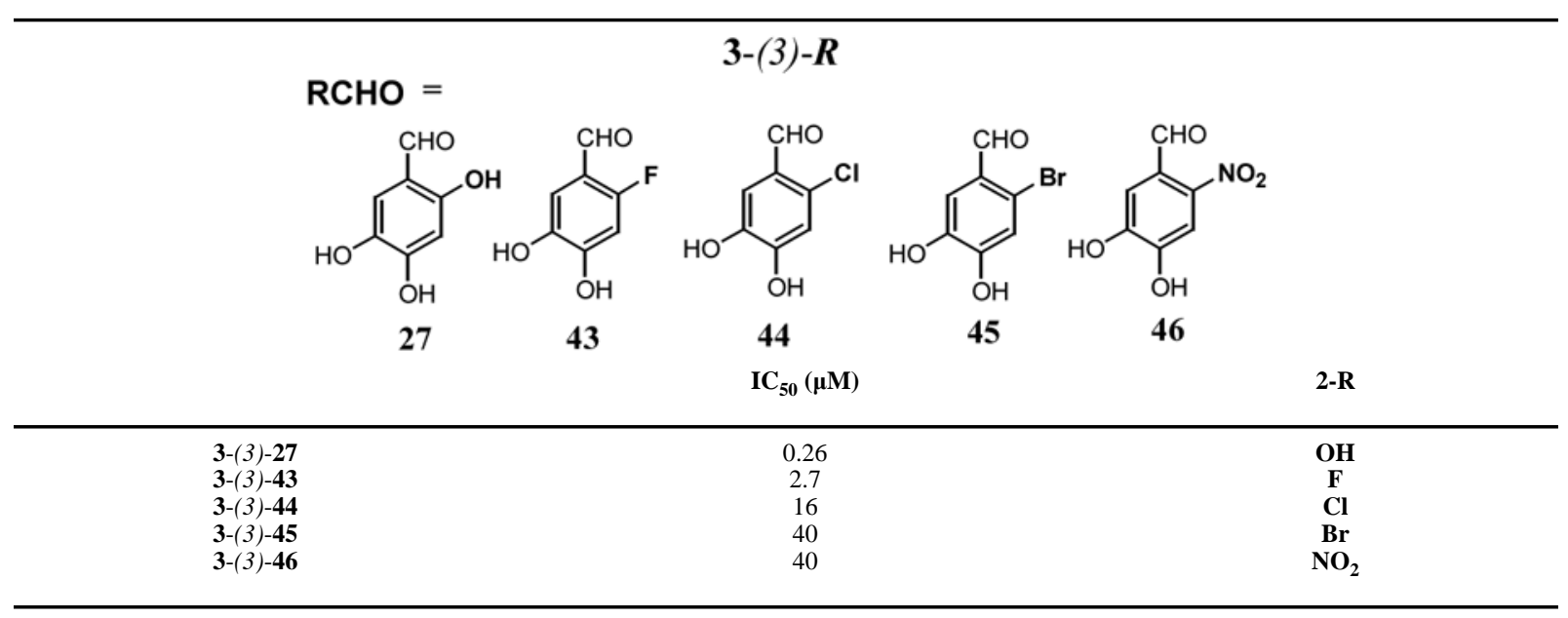

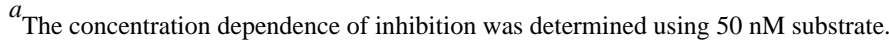


Table 3

Inhibition Constants for Uracil and its Derivatives ${ }^{a}$

\begin{tabular}{|c|c|c|c|c|}
\hline Parameter & $3-(3)-27$ & $2-(2)-13$ & Uracil & 51 \\
\hline$K_{\mathrm{s}}(\mu \mathrm{M})$ & $0.19 \pm 0.02$ & $0.23 \pm 0.03$ & $0.23 \pm 0.02$ & $0.16 \pm 0.01$ \\
\hline$k_{\text {cat }}\left(\mathrm{s}^{-1}\right)$ & $0.41 \pm 0.01$ & $0.50 \pm 0.02$ & $0.47 \pm 0.01$ & $0.33 \pm 0.01$ \\
\hline$k_{\text {cat }}\left(\mathrm{s}^{-1}\right)$ & $0.16 \pm 0.04$ & $0.012 \pm 0.02$ & $0.06 \pm 0.01$ & - \\
\hline$K_{\mathrm{c}}(\mu \mathrm{M})$ & $0.32 \pm 0.02$ & - & $80 \pm 7$ & $45 \pm 2$ \\
\hline$K_{\mathrm{n}}(\mu \mathrm{M})$ & - & $2.8 \pm 0.1$ & - & - \\
\hline$K_{\mathrm{n}}^{\mathrm{c}}(\mu \mathrm{M})$ & $1.2 \pm 0.2$ & - & $300 \pm 55$ & - \\
\hline$K_{\mathrm{n}}^{\mathrm{s}}(\mu \mathrm{M})$ & $1 \pm 0.3$ & $125 \pm 46$ & $104 \pm 7$ & - \\
\hline Mode of Inhibition & $\begin{array}{c}\text { Two sites, } \\
\text { competitive, partial } \\
\text { uncompetitive }\end{array}$ & $\begin{array}{l}\text { One site, partial } \\
\text { mixed-type }\end{array}$ & $\begin{array}{c}\text { Two sites, } \\
\text { competitive, partial } \\
\text { uncompetitive }\end{array}$ & One site, competitive \\
\hline
\end{tabular}

\footnotetext{
${ }^{a}$ Parameters correspond to the mechanisms shown in Scheme 1. $K_{\mathrm{C}}$ and $K_{\mathrm{n}}$ represent dissociation constants for inhibitor binding sites that are competitive and noncompetitive with substrate, respectively. $K_{\mathrm{n}} \mathrm{c}$ and $K_{\mathrm{n}} \mathrm{s}$ represent the dissociation constants for inhibitor binding to the noncompetitive site when the active site is occupied by the competitively bound inhibitor or substrate, respectively. In these simulations the Michaelis-Menten parameters for the substrate were fixed using values from nonlinear regression fits (Fig. 6). Other parameters were obtained from simulations to the data using the program Dynafit (cf. Supplemental Information)
} 